\title{
An Insight into Children's Literature: A Reading of Luisa May Alcott's Little Women
}

\author{
Dr. Heba Maher Attia Hashim \\ Lecturer in English Literature, Department of English, \\ Faculty of Arts, New Valley University, Egypt.
}

\begin{abstract}
Drawing on the nature and development of children's literature in the English Language, the present paper provides a reading of Luisa May Alcott's Little Women, a book with which young readers have instantly fallen in love. The novel traces the lives of four sisters who belong to a poor but loving family. In this paper, the researcher attempts to show how each of the four sisters is determined to accomplish her ambitions and attain her aspirations. With their father off to war, Meg, Jo, Beth, and Amy March have only their mother left to be an inspiring power for them. The wise mother nurtures her young daughters with love and self-dependence, encouraging them to adhere to their love for each other and become the best version of themselves at all times. Throughout their lives, the four girls go through success and failure, love and loss, and do learn to face life, bear responsibility, and support each other. Alcott vividly depicts the passage of the four sisters from early childhood into adulthood as they remarkably grow into perfect 'little women' who can outstandingly achieve their goals in life. Finally, the paper presents a number of critical issues related to women and their stance in society. More importantly, the example of the four girls in Little Women provides young readers with an insight into how to plan for their lives, achieve the success they yearn for, and accordingly contribute to the stability and happiness of their families.
\end{abstract}

\section{Keywords:}

Children's Literature, Little Women, Luisa May Alcott.

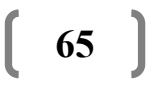




\section{مجلة وادي النيل للاراسات والبحوث الإنسانية والاجتماعية والتربوية (مجلة علمية محكمة)}

(ISSN : 2536 - 9555)

نظرة في أدب الأطفال: قراءة في رواية نساء صغيرات لـ "لويزا ماي ألكوت"

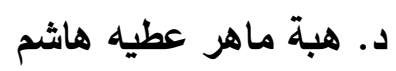

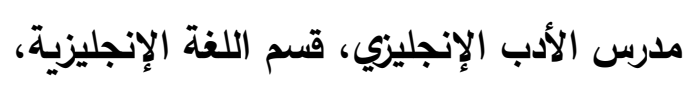

كلية الآداب، جامعة الوادي الجديد، مصر.

تهدف هذه الورقة البحثية إلى تقديم قراءة - من منظور أدب الأطفال -

في رواية نساء صغيرات للكاتبة "الويزا ماي ألكوت". تسرد الرواية قصة أستة أسرة

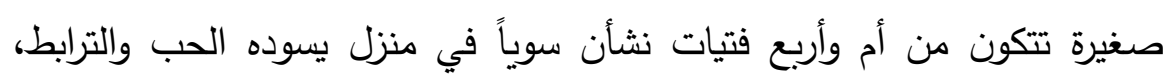

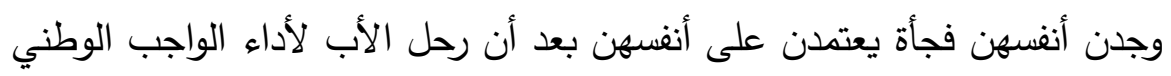

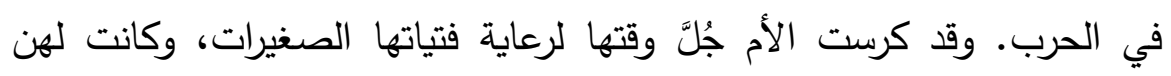

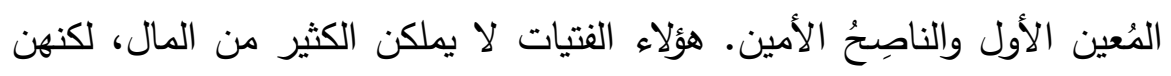

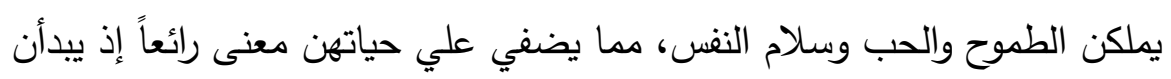
في التحول عمرياً من فتيات صغيرات إلى نساء صغيرات يتحملن المسئولية

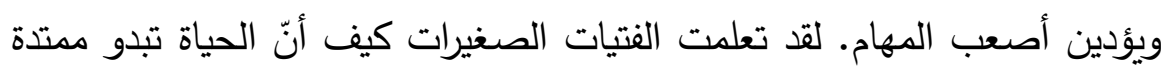

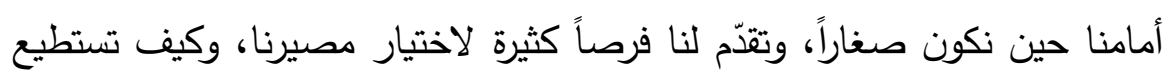

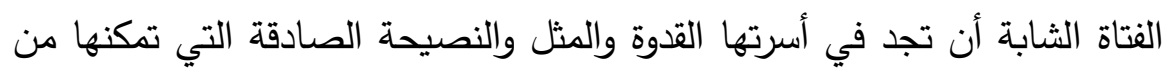
اختيار الطريق الصحيح. وهكذا تحمل رواية نساء صغيرات رسالة عالمية ايجابية يمكن للفتيات الصغيرات أينما ثقتوا اقتفاء أثرها والاستفادة منها من خلاء الصاء المثال

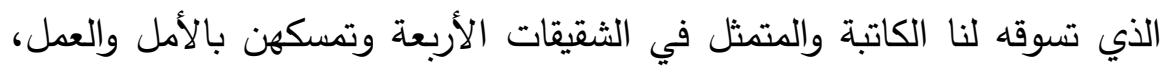
وإصرارهن على أن يصبحن فتيات ناجحات يستطعن أن يحققن أحلامهن، ويثبتن ذواتهن. كلمات مفتاحية: أدب الأطفال، نساء صغيرات، لويزا ماي ألكوت. 


\section{An Insight into Children's Literature: A Reading of Luisa May Alcott's \\ Little Women}

مجلة وادي النيل للاراسات والبحوث الإنسانية والاجتماعية والتربوية (مجلة علمية محكمة)

My dear girls, I am ambitious for you, but not to have you make a dash in the world, marry rich men merely because they are rich, or have splendid houses, which are not homes because love is wanting....I'd rather see you poor men's wives, if you were happy, beloved, contented, than queens on thrones, without self-respect and peace.

— (Alcott, Little Women 105)

So states Marmee, the mother who wisely advises her four daughters, expressing her wishes for them and urging them to leave a mark on the world so that they can lead a happy life characterized with love, content, 'self-respect', and 'peace'. It is worth noting that Mr. March is away from home, taking part in the American Civil War, and Marmee finds herself fully responsible for guiding her daughters and instilling the good values in them in order to prepare the young girls for life and its countless responsibilities. On their part, the four daughters find in their mother the model they pursue and return to in times of trouble and hardship. Following on the footsteps of their mother, the March sister can weave their hopes, overcome their pains, and draw for themselves a definite path through which they can assert themselves as distinguished girls. This is how the wise mother enthusiastically pushes her young daughters into success and achievement: "Our burdens are here, our road is before us, and the longing for goodness and happiness is the guide that leads us through many troubles and mistakes to the peace which is a true Celestial City" (11). 
(ISSN : 2536 - 9555)

Best known for her children's books, particularly her novel Little Women, Luisa May Alcott is a well-known American writer whose literary production varies including novels, short stories, poems, plays, and children's works. In her children's novels, she "champions women's rights, questions the way male-dominated society functions, and lets her heroines dream about more than husbands and homes " (Lenahan 3). Alcott is generally recognized as "the greatest and most popular story-teller for children in her generation," Cheney states, pointing out that Alcott "has known the way to the hearts of young people, not only in her class, or even country, but in every condition of life, and in many foreign lands" (III).

Children's literature can be defined as these literary works which are composed for entertaining children, instructing them, and instilling the desired behaviour and good values in them. Children's Literature has many characteristics. It is simple, clear, and straightforward. It is characterized by fantasy and has no major concern of reality. Hope and optimism are two important features of children's literature. There is a tone of joy and innocence running through the literary works composed for children. A literary work intended for children usually emphasizes repetition as a major technical device that suits young readers' learning. That is why repetition is a common component of traditional tales, folk tales, and fairy tales (Sweetland). Significantly, subject in children's literature is remarkably "at the advantages of form, language and ways of artistic material," writes Mirjana Stakić, arguing that the "literary text has to be interesting to children and to respond to their large and diverse interests, so that children's literature is characterized by large thematic richness and layers" (243). Children's literature includes actions and events related to childhood and has characters that are children. In other words, children's literature addresses children and is centered around their world. As Barbara Wall states,

All writers for children must, in a sense, be writing down. If they write with an educated adult audience

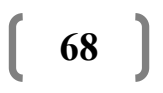




\section{An Insight into Children's Literature: A Reading of Luisa May Alcott's \\ Little Women}

Dr. Heba Maher Attia Hashim,

مجلة وادي النيل للاراسات والبحوث الإنسانية والاجتماعية والتربوية (مجلة علمية محكمة)

in mind - their own peers - their stories will surely be, at best not always interesting.... Whenever a writer shows consciousness of an immature audience, in the sense of adapting the material of the story or the techniques of the discourse for the benefit of child readers, that writer might be said to be writing down, that is, acknowledging that there is a difference in the skills, interests and frame of reference of children and adults. (15)

In the introduction to his book entitled Understanding Children's Literature, Peter Hunt points out that "children's books have a long history..., and they have absorbed into themselves elements of folk and fairy tale, and the oral tradition"(5). In the fifteenth century, hornbooks were invented introducing young readers to the alphabet, the numerals, and the prayers. According to Oxford Dictionary of Phrase and Fable, a hornbook is "a former teaching aid consisting of a leaf of paper showing the alphabet, and often the ten digits and the Lord's Prayer, mounted on a wooden tablet and protected by a thin plate of horn" (170). During the same century, precisely in 1476, William Caxton brought printing to England, giving children the chance to read and enjoy printed books for the first time. Two important children's works which Caxton printed and published during that time were Aesop's Fables in1484 and Sir Thomas Malory's Le Morte d'Arthur or The Death of Arthur in 1485.

In the sixteenth century, the courtesy books and etiquette guides widely spread, teaching children morals, etiquette, and the appropriate bahaviour. A moralistic and didactic focus characterized the works written for children during that time. Outstanding among these works was Erasmus of Rotterdam's A Handbook on Good Manners for Children, a book that was first published in Latin in 1530 and then translated into English in 1532. 
(ISSN : 2536 - 9555)

In the seventeenth century, chapbooks emerged as an effective means for instructing and entertaining children. Those chapbooks were often sold by chapmen or peddlers. A chapbook can be described as a pamphlet or a small book that contains popular tales, stories, poems, ballads, religious tracts, and nursery rhymes. It is worth mentioning that in 1658, the famous philosopher John Comenius published a significant book titled The World of Things Obvious to the Senses Drawn in Pictures which was regarded by critics as the first picture-book for children.

The eighteenth century witnessed the emergence of the first true book for children. According to Perry Nodelman, this was in 1744 when the English writer and publisher John Newbery who was called the father of children's literature published A Little Pretty Pocket-Book: Intended for the Instruction and Amusement of Little Master Tommy and Pretty Miss Polly (17). Other important children's works that were published during that century are Daniel Defoe's Robinson Crusoe (1719), Jonathan Swift's Gulliver's Travels (1726), and Elizabeth Newbery's Tales from the Arabian Nights (1791, one of the greatest works in Arabic literature.

In the nineteenth century, children literature was increasingly going into its golden age, with children's authors focusing on adventure, fun, and modern fantasy. The two brothers Jacob and Wilhelm Grimm published Nursery and Household Tales (1812). Widely recognized as the father of modern fairy tale and fantasy, Hans Christian Anderson produced his important work Fairy Tales in 1835. Other significant children's works that appeared during that century were Lewis Carroll's Alice's Adventures in Wonderland (1865), Louisa May Alcott's Little Women (1868), and Mark Twain's Adventures of Tom Sawyer (1876).

In the twentieth century, English language children's literature developed in a notable way as it was recognized as a distinct field of its own, "with its own space in public libraries, its own graduate programs, and its own respected journals" (Stevenson 2011). This clearly noted development was reflected in 
An Insight into Children's Literature: A Reading of Luisa May Alcott's

Little Women

Dr. Heba Maher Attia Hashim,

مجلة وادي النيل للاراسات والبحوث الإنسانية والاجتماعية والتربوية (مجلة علمية محكمة)

works such as L. Frank Baum's The Wonderful Wizard of $\mathrm{Oz}$ (1900), Frances Hodgson Burnett's A Little Princess (1905), Hugh Lofting's The Story of Doctor Dolittle (1920), A. A. Milne's Winnie-the-Pooh (1926), and Dr. Seuss's And to Think I Saw It on Mulberry Street (1937). Other important works that enriched the child's library during that century were Roald Dahl's Fantastic Mr. Fox (1970). Shel Silverstein's The Giving Tree (1964), Patricia MacLachlan's Sarah, Plain and Tall (1985), Lois Lowry's The Giver (1993), Philip Pullman's The Amber Spyglass (2000).

The twenty-first century, with its great technologies, contributed very clearly to the development of children's literature. With the wide spread of electronic devices such as tablets, laptops, smartphones, and kindle, digital books became very common and children could use them very easily. Outstanding among the works produced for children in the twenty-first century are Mark Haddon's The Curious Incident of the Dog in the Night-Time (2003), Jeff Kinney's Diary of a Wimpy Kid (2007), Jennifer Richard Jacobson's Small as an Elephant (2011), Michael Morpurgo's Flamingo Boy (2018), and David Walliams' Fing (2019).

Published in 1868, Alcott's Little Women is based on the novelist's own life introducing "a new genre for children. The four March girls aged 16 to 12, named in the subtitle as Meg, Jo, Beth and Amy, present the readers with alternative options for coming of age and finding their identity" (Egeland 316). The more the events of the narrative develop, the more we admire the four girls, appreciate their strong will, and "become "privy to their dreams and disappointments, their squabbles and collective imagination, the immediate world they learn to maneuver" (Smith). Though their father, Mr. March, is away from home, the four girls find compensation in their mother, Marmee, who outstandingly 
مجلة وادي النيل للاراسات والبحوث الإنسانية والاجتماعية والتربوية (مجلة علمية محكمة)

(ISSN : 2536 - 9555)

succeeds in playing the two roles of mother and father at the same time.

Despite the financial difficulties the family faces, the girls still lead a happy life thanks to their mother who strongly fights for her daughters, instilling in them the spirit of challenge and the insistence to overcome their difficult circumstances and have a distinguished status in society. In his article "The Hidden Feminist Agenda and Corresponding Edification in the Novel Little Women by Louisa May Alcott," Shai Rudin sees that Alcott's Little Women is a clear opposition to Adrienne Rich's claims that the relationships between mothers and daughters were marginalized by society and became a story that have not yet been written to this very day. Strongly rejecting this view, Rudin argues that Little Women is outstandingly "a proof of the centrality and eternalness of the connection between mothers and daughters," illustrating how in the novel

Mrs. March challenges patriarchal motherhood that "produces" daughters who internalize chauvinistic patterns of behavior, and...does not educate women to fulfill roles completely distinct from male roles. She even notes that "...better be happy old maids than unhappy wives" (Little Women, p. 168). She educates her daughters and Laurie, who sees her as a mother, to marry for love so as not to be subjugated to a rich man who would most likely treat them as an object. Mrs. March preaches honest work and does not want her daughters to be mere decorations for male society. (126)

Accordingly, each of the four girls has a dream to pursue and a goal to achieve, looking at their mother as a model and an inspiring figure that supports and encourages them to find their own ways in life and become highly recognizable and ideal 'little women'. Ambition, determination, self-confidence, and love for each other

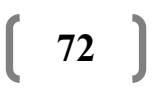




\section{An Insight into Children's Literature: A Reading of Luisa May Alcott's \\ Little Women}

Dr. Heba Maher Attia Hashim,

مجلة وادي النيل للاراسات والبحوث الإنسانية والاجتماعية والتربوية (مجلة علمية محكمة)

are the factors that help the March girls confront their harsh reality and go into the path of success and distinctiveness which they have drawn for themselves from the start of the narrative.

The oldest of the four March sisters is Margaret or Meg. She is depicted by Alcott as a typical girl of the nineteenth-century American society who is both mature and responsible. She is pretty, sweet-natured, kind, patient, dutiful, and mother-like. Whenever the mother is away from home, she works as a second mother, doing the household, caring for her younger sisters, and acting as a perfect little woman who sees her role in life as significant as the role played by any young man who finds himself responsible for his family. This image in which Meg sees herself and her position in society evokes an important issue in the novel, namely, feminism and gender stereotyping. Throughout Little Women, Alcott skillfully "breaks traditional gender stereotypes..., encouraging her readers not to label themselves or others simply based on gender. By transcending the normal rules of the time, Alcott encourages people to see each other as equals" (Bender 151).

Romantic in nature, Meg yearns to have a great life. However, her main goal in life is to support her family and help her sisters grow into successful little women. To help her family, Meg works as a governess for children at the house of a wealthy family called the Kings, and thus feels proud to bear responsibility and give her mother a hand in looking after her younger sisters. Meg sees herself as a bearer of responsibility. As she grows up into a beautiful woman, Meg marries John Brooke. This is how Alcott describes the good-natured Meg at her wedding day: 
مجلة وادي النيل للاراسات والبحوث الإنسانية والاجتماعية والتربوية (مجلة علمية محكمة)

(ISSN : 2536 - 9555)

Meg looked very like a rose herself, for all that was best and sweetest in heart and soul seemed to bloom into her face that day, making it fair and tender, with a charm more beautiful than beauty. Neither silk, lace, nor orange flowers would she have. "I don't want a fashionable wedding, but only those about me whom I love, and to them I wish to look and be my familiar self." So she made her wedding gown herself, sewing into it the tender hopes and innocent romances of a girlish heart. (278)

Though Meg and John have to live in a modest house and though their economical circumstances are not very high, they lead a happy life which becomes happier and more meaningful after they have three children: Daisy, Demi, and Josie. Even after marriage, Meg remains the shelter, the warmth, and the solidity on which her younger sisters can still rest their heads. As she has successfully proved at the beginning of the book to be an ideal little woman, Meg comes at the end to attract the reader's attention as a highly respectable and recognizable young woman.

The second oldest sister in the March family, Josephine or Jo, is the heroine of Little Women. Her character is mainly based on the character of Alcott herself. Having a great passion for writing, Jo aspires to be a famous writer. From the start, she is determined to work hard in order to satisfy her thirst for knowledge and accomplish her literary aspirations. She enthusiastically expresses her wishes and yearnings stating,

I want to do something splendid before I go into my castle, something heroic or wonderful that won't be forgotten after I'm dead. I don't know what, but I'm on the watch for it, and mean to astonish you all some day. I think I shall write books, and get rich and famous, that would suit me, so that is my favorite dream" (164).

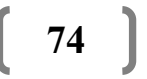




\section{An Insight into Children's Literature: A Reading of Luisa May Alcott's \\ Little Women}

Dr. Heba Maher Attia Hashim,

مجلة وادي النيل للاراسات والبحوث الإنسانية والاجتماعية والتربوية (مجلة علمية محكمة)

In fact, Jo's dreams go beyond the domestic sphere and show her as untraditional and adventurous. Unlike Meg, Jo is hot-tempered, rebellious, and independent. Alcott depicts her heroine's character in a way that challenges the typical model of women in nineteenthcentury America who were completely devoted to purity, piety, domesticity, and submissiveness. Unlike these traditional stereotypes, Jo is ready to break the traditional rituals of society and seek what she herself thinks is correct and acceptable. However, she loves her sisters so much and is keen to see her family coherent and happy.

Jo decides to work in order to earn money and help the family. So, she works as a companion to her rich elderly Aunt March. Later in the book, she loses this job and works as a governess in New York. When her father, Mr. March falls ill and her mother, Marmee, wants to travel to Washington to see him, Jo makes up her mind, without hesitation, to sell her hair, which she regards as her only pride, in order to save her mother the price of the ticket.

Through the character of Jo, Alcott's attracts the attention of young readers that our families should be the most important concern for us. Accordingly, we should do our best to sustain them and respond at once to any call of help from them, simply because families are "The Most Beautiful Things in All the World," to quote the title of Elizabeth Keyser's article inspired to the critic by Jo herself. Keyser points out, "Alcott's conflicted, problematical relationship with her own family..., as well as her choice to remain single, suggest that she viewed the Victorian family realistically, if not skeptically" (50). At the end of Little Women, Jo states, "I do think that families are the most beautiful things in all the world!" (530). 
(ISSN : 2536 - 9555)

In New York, Jo meets Professor Friedrich Bhaer and befriends him. To earn extra money, Jo starts to sell some of the stories she has written. Knowing that the health of her sister Beth has fallen, Jo at once comes home back, devoting her time to caring for her dying sister. At the beginning of the book, Jo refuses the idea of marriage, arguing that marriage may take her away from her beloved sisters and parents. That is why she rejects the proposal made by Theodore Laurie, the family's neighbour and her own close friend. However, she later begins to fall in love with Professor Bhaer whom she has met in New York.

When Jo leaves New York, Professor Bhaer visits the March family and spends two weeks at their home. He then proposes for Jo who accepts to marry him. "His clothes were rusty, his hands were large, and he hadn't a really handsome feature in his face, except his beautiful teeth," Jo narrates in the novel, describing Professor Bhaer, "yet I liked him, for he had a fine head, his linen was very nice, and he looked like a gentleman" (370). Not only has Jo achieved her literary aspirations as a writer, but she has also succeeded in supporting her sisters financially and emotionally, stayed beside her sick sister all time, helped to keep the family coherent and solid, married a gentleman who truly loves her, had two boys, established a school for boys with her husband Bhaer, and enjoyed a happy life with her husband and children. Thus, Alcott's portrayal of the character of Jo impressively convinces us as readers that she, Jo, distinctively passes from the stage of a perfect little woman at the beginning of the novel into an impressive young lady at its end. According to Hayley Lenahan, 'Jo and Friedrich's marriage is more satisfying to the reader than John and Meg's'. Lenahan argues:

While John is proud of his pretty wife, Friedrich is utterly devoted to his spirited one. Years and two sons into their marriage, in Jo's Boys, Friedrich's love for Jo is still clear: "the Professor forgot his piles of letters to admire the pleasing prospect of his

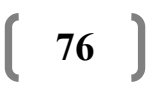




\section{An Insight into Children's Literature: A Reading of Luisa May Alcott's Little Women}

Dr. Heba Maher Attia Hashim,

مجلة وادي النيل للاراسات والبحوث الإنسانية والاجتماعية والتربوية (مجلة علمية محكمة)

wife" (Chap.7). Friedrich gets some credit from the reader because the reasons he loves his wife are the same reasons the reader loves her: Jo is smart, lively, generous, and good-hearted. (43)

Quiet, sweet, shy, and angelic in nature, Elizabeth or Beth is the third March sister. She always attempts to please others and help them. She loves music and finds great fun in playing the piano. Alcott portrays her as the peacemaker of the March family. She is a rich source of compassion and tenderness for her sisters. Like her elder sisters, she is keen to support her family and hold its members together. The character of Beth embodies an important value which Alcott cleverly teaches for children reading her book; this is the value of home as a place that provides the person with empowerment, self-assurance, and relief. It is the place which makes the person stronger, more confident, and more capable of changing negative feelings into positive ones. Addressing the same issue, Stephanie Foote argues that the characters in the novel "endure a series of mortifying confrontations with their own social inadequacies, and that they therefore experience astonishingly negative emotions" (81). Despite this, Foote further points out,

[T] he novel is not about negative emotions; rather it is a novel that resolves negative emotions without always repressing them. It understands the domestic as a way to transform such negative emotions by understanding the home as a place where social distinctions can be learned, practiced, and reconfigured as 'natural' distinctions" (81).

Remarkably, Beth is very close to Jo and she often tells her about her secrets and plans Critics see that Beth is too angelic and too virtuous to live the realistic world depicted for her by Alcott. Beth's main goal in life is to see her sisters happy and successful. 
(ISSN : 2536 - 9555)

Unfortunately, she develops scarlet fever and has to stay at home. Despite her failing health, Beth has never stopped to help other people and make them feel happy and satisfied. These rich doses of love and kindness are not confined to the members of her family but they also extend to include people whom she does not know. For example, she waits for children who pass her family house in their way to school and gives them beautiful things she herself sews for them.

However, innocent Beth finally dies, causing a deep wound inside the March family and leaving a harsh, materialistic world in which her angelic qualities can find no place. Despite her short life, Beth has achieved an important thing in the narrative. She has given a perfect example of the enduring little woman who can give and love- very generously, finding her greatest happiness in keeping others pleased and content. Even in her last breath, Beth never forgets her family. While on her deathbed, she advises her closest sister Jo, saying,

"Jo, ...be everything to Father and Mother when I'm gone. They will turn to you, don't fail them, and if it's hard to work alone, remember that I don't forget you, and that you'll be happier in doing that than...seeing the entire world, for love is the only thing that we can carry with us when we go, and it makes the end so easy." (459)

The youngest of the four sisters, Amy is the spoiled child of the March family. She is a beautiful child with golden hair and blue eyes. Since childhood, she has been fond of visual arts such as painting, sketching, and sculpting. Her artistic talents make her sisters call her the artist of the family. An artistic beauty, she is a genuine and interesting character who has the skill of influencing other people very easily. The great aim which Amy tries hard to achieve in life is to be a gentlewoman. Perhaps the most important feature of her character is that she knows her goal very precisely.

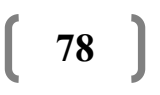




\section{An Insight into Children's Literature: A Reading of Luisa May Alcott's \\ Little Women}

Dr. Heba Maher Attia Hashim,

مجلة وادي النيل للاراسات والبحوث الإنسانية والاجتماعية والتربوية (مجلة علمية محكمة)

She is confident of herself and she is ready to overcome any obstacle that hinders the way of her aspirations. In her own words,

"I'm not afraid of storms, for I'm learning how to sail my ship" (498).

Through the character of Amy, Alcott attempts to instill the values of challenge, insistence and optimism in her young readers. When Amy loses a chance, she never laments the loss but rises again, full of hope and enthusiasm to have a better opportunity than that she has missed. This is principally what Laurie, the family's neighbour, likes in her, "the spirit with which she took up a new purpose," writes Alcott in the novel, "when a long cherished one died, and spent no time lamenting" (445). That's why she gets all she has dreamt of at the end, particularly travelling to Europe, attaining the popularity she has aspired to, and marrying a gentleman. She finally gets married to Laurie whom she loves and prefers to the wealthy Fred Vaughn, following her mother's advice "not to...marry rich men merely because they are rich, or have splendid houses, which are not homes because love is wanting" (105). She has thus realized that love is more important than money, and that 'self-respect and peace' are the real bases of marriage. She can still get the money she likes to have since the man she has chosen, Laurie, is also rich but not of course as rich as the wealthy Fred Vaughn.

To sum up, Alcott's Little Women shows how the March girls grow into responsible gentlewomen who determinedly pursue their goals in life, and successfully achieve their aspirations. Following on the footsteps of their wise mother and considering the principles they have learnt from their absent father, the four sisters succeed to be perfect models for the striving and hard working young women. The novel serves as a touchstone that 
مجلة و ادي النيل للاراسات والبحوث الإنسانية والاجتماعية والتربوية (مجلة علمية محكمة)

(ISSN : 2536 - 9555)

highlights women's position in society. Alcott proficiently presents a range of choices for the four sisters,

from Jo's desire for a professional writing career to Meg's preference for a more traditional domesticity. Alcott's technique of focusing some chapters on one particular sister while creating other chapters that consider all four sisters as part of a family unit provides opportunities to learn more about each sister as an individual but also maintains a sense of shared experiences. (Hubler et al. 454)

Aspiring to "goodness and happiness", as their mother affirms, the girls pass through "many troubles and mistakes," several strains and delights, till they finally accomplish their ambitions, reap the fruits of their hard work, and find what Alcott calls "the peace," self-assertion and satisfaction which they have dreamt of (11). Though the narrative has been disturbed by the tragic event of Beth's death which saddens the family and causes a gloomy atmosphere to hang all over the house, it finally "brings success and contentment to the surviving members of the March family, and by the end of the novel, Jo, Amy and Meg are happily married and are laboring in the fields best suited to the strengths as well as the weaknesses of their personalities" (Foote 69).

Little women provides young readers with an insight into how to face the difficulties of life, discover themselves, and work hard to achieve what they dream of. In the book, Alcott invites these young readers to investigate the world of the March girls who have decided to confront life with love and ambition. In the words of Hayley Lenahan,

Children recognize these values from their own families and from their lives. Because the book supports values they already possess, they wish to share additional, new values... with the "imagined

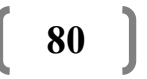




\section{An Insight into Children's Literature: A Reading of Luisa May Alcott's \\ Little Women}

Dr. Heba Maher Attia Hashim,

مجلة وادي النيل للاراسات والبحوث الإنسانية والاجتماعية والتربوية (مجلة علمية محكمة)

community" of other readers and also with the Marches' community, the characters they love from Little Women. Alcott's use of her art as literary activism to open minds was her greatest contribution to the women's movement. (28)

As a female author of Little Women, Alcott provides a source of origin and reality in her work, consequently adding an autobiographical dimension to the novel. This is what Kristina West indicates in her article entitled "Who Owns Little Women? Adapting Alcott in the Twenty-First Century." The article raises an interesting point about the novel, namely, the issue of textual origin. West argues that Little Women, like other works of fiction,

had a life prior to the text. Alcott herself claimed that '[w]e really lived most of it,' resulting in an autobiographical reading that still informs most criticism of Little Women. As such, a substantial part of its narrative and the characters that inhabit it are claimed to be drawn from the author's own life; preexisting, therefore, the ostensibly fictional text" (410).

A significant point to conclude with is that Alcott, in Little Women, challenges women's traditional roles and gives her characters the space to rebel against the female reality and look for new stances for them in life. The novelist has achieved this task sought by her female characters through "celebrating and critiquing their positions in the private sphere and calling for the creation of new roles for women in the public sphere" (Lenahan 6). This is what exactly happens in Little Women. Though the civil war has imposed bad social and financial conditions on the March sisters especially after the father has gone to participate in the war, the mother enthusiastically fights for her striving daughters. On their 
(ISSN : 2536 - 9555)

turn, the young girls have the power to celebrate their domestic roles and publicly create new ones that help them accomplish their ambitions as successful and distinguished little women.

\section{References}

Alcott, Luisa May. Little Women. Illustrated by Jessie Willcox Smith. GlobalGrey, 2018.

Bender, Clare. "Gender Stereotyping in Little Women: Let

Us Be Elegant or Die!” MJUR, Issue 8, 2017. pp,140-153.

Cheney, Ednah."Introduction." Louisa May Alcott: Her Life,

Letters, and Journals. Ednah Cheney, editor. Applewood Books, 2010. pp. III-V.

Egeland, Marianne. "Little Women Travelling to Scandinavia: The Reception of Louisa M. Alcott in Sweden, Denmark and Norway." European Journal of Scandinavian Studies, vol. 50, no. 2, 2020.pp. 314-334.

Foote, Stephanie. "Resentful Little Women: Gender and Class Feeling in Louisa May Alcott." College Literature, vol. 32, no.1, 2005, pp. 63-85.

Hubler, Angela, et al. " Roundtable: Teaching Little Women." Women's Studies, vol. 48, no. 4, 2019. pp. 446-458.

Hunt, Peter. "Introduction: The World of Children's Literature Studies." Understanding Children's Literature. Peter Hunt, editor. Routledge, 2002. 
An Insight into Children's Literature: A Reading of Luisa May Alcott's

Little Women

Dr. Heba Maher Attia Hashim,

مجلة وادي النيل للاراسات والبحوث الإنسانية والاجتماعية والتربوية (مجلة علمية محكمة)

Keyser, Elizabeth Lennox. "The Most Beautiful Things in All the World'? Families in Little Women." Stories and Society: Children's Literature in its Social Context. Dennis Butts, editor. Palgrave Macmillan UK, 1992. pp.50-64.

Lenahan, Hayley Miller, "Domestic and Subversive: The Roles of Women in the Children's Novels of Louisa May Alcott" (2012).Honors Thesis Collection.50. Retrieved from: https://repository.wellesley.edu/thesiscollection/50. Accessed June 23, 2020.

Nodelman, Perry. The Pleasures of Children's Literature. Longman Publishing Group, 1992.

Oxford Dictionary of Phrase and Fable. (2006). 2nd ed. Oxford University Press. Retrieved from: https://www.oxfordreference.com/view/10.1093/acref/9780198609 $\underline{810.001 .0001 / \text { acref-9780198609810-e- }}$ 3407?rskey=5klcKo\&result=3399. Accessed January 18, 2021.

Rudin, Shai. "The Hidden Feminist Agenda and Corresponding Edification in the Novel Little Women by Louisa May Alcott". Childhood, vol. 3, 2019. pp. 115-132.

Smith, Patti. "A Responsible Freedom: Patti Smith on Little

Women." The Paris Review, 2018. Retrieved from:

83 
مجلة وادي النيل للاراسات والبحوث الإنسانية والاجتماعية والتربوية (مجلة علمية محكمة)

(ISSN : 2536 - 9555)

https://www.theparisreview.org/blog/2018/09/24/a-

responsible-freedom-patti-smith-on-little-

women/.Accessed February 12, 2021.

Stakić, Mirjana. "The Specifics of Children's Literature in the Context of Genre Classification." Mediterranean Journal of Social

Sciences, vol. 5, no. 19, 2014. pp. 243-251.

Stevenson, Laura C. "Literary Ladders in the Golden Age of Children's Books." The Sewanee Review, vol. 119, no. 3, 2011. pp. 428-444.

Sweetland, Robert, "What is Children's Literature?" Retrieved from:

http://www.homeofbob.com/literature/curriculum/characrist csChildLit.htm. Accessed April 20, 2021.

Wall, Barbara. The Narrator's Voice: The Dilemma of Children's Fiction. Macmillan, 1991.

West, Kristina. "Who Owns Little Women? Adapting Alcott in the Twenty-First Century." Women's Studies, vol.48, no. 4, 2019. pp. 407-420. 